\section{Serological Relationships in the Genus Gadus}

LrTtue information is available concerning the serological relationships of fishes, and virtually nothing is known concerning the serology of the economically important genus Gadus.

Three species from this genus have been investigated in our laboratory, namely, the cod (Gadus callarias L.), the haddock (G. aeglifinus L.) and the pollack (G. pollacius L.). Blood was obtained from these three species by opening the animal after stunning, and taking it directly from the heart. The blood was allowed to clot, the serum separated, and merthiolate added to give a concentration of $I: 10,000$. The stock of rabbits used proved rather refractory, and the potency of the antisera was lower than might have been hoped. Three moderately satisfactory antisera were obtained, the first an anti-haddock serum $R 71$, and two anti-cod sera $R 72$ and $R 712$. Each of these antisera was produced after a course of intravenous injections of the fish serum. In the case of the anti-haddock serum, the intravenous course was followed, after a month's rest, by one series of intraperitoneal injections. In the case of the anti-cod serum, $R 712$, the second series of injections were subcutaneous. Anti-cod serum $R 72$ was produced by a single course of four intravenous injections. The amount used for each injection was $0.25 \mathrm{ml}$. of serum, and a course consisted of either three or four injections, given on alternate days. The characteristics of the antisera are shown in Table 1.

Table 1. Characteristics of the Antisera

\begin{tabular}{|c|c|c|c|}
\hline Antiserum & $\begin{array}{c}\text { Serum used } \\
\text { from: }\end{array}$ & $\begin{array}{c}\text { Reciprocal of } \\
\text { homologous titre }\end{array}$ & $\begin{array}{c}\text { Homologous } \\
\text { photroner curve } \\
\text { area }\end{array}$ \\
\hline $\begin{array}{c}R \\
R\end{array}$ & Haddock & 1,000 & 107 \\
$R 712$ & Cod & 1,000 & $84 \cdot 5$ \\
$92 \cdot 8$
\end{tabular}

The serological correspondence between the various species was determined using the photronreflectometer as described by Boyden and Delfaco ${ }^{1}$. The relationship ratios are given in Table 2 . These ratios are calculated by expressing the area under the curve ( $\sigma \tau$ value) of the second of the pair being compared as a percentage of the first. The reciprocal figures are also included (asterisks). Thus the cod/ pollack ratios are derived from curves for antisera $R 712(100: 21)$ and $R 71 \quad(27: 100)$. The eurves obtained from antiserum $R 71$ are shown in Fig. 1 .

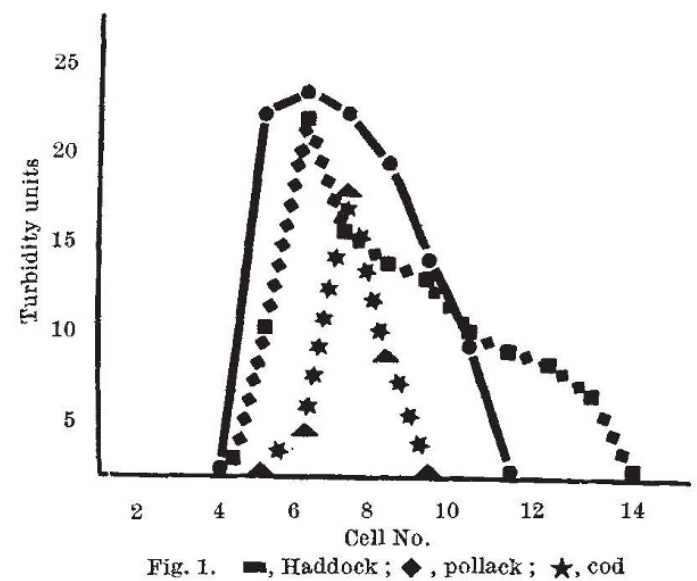

Table 2. ReLationship Ratios

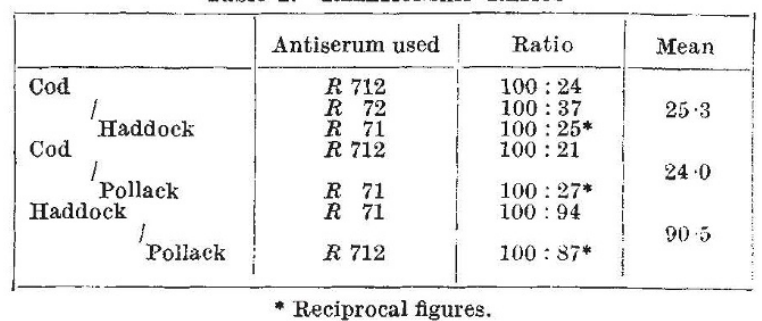

It will be seen that serologically haddock and pollack are closely related and that the cod is about equally remote antigenetically from both.

We are grateful to the Medical Research Council of Ireland for a grant to purchase the photronreflectometer used in these studies and to the Director, and Mr. R. J. Beverton, of the Lowestoft Fisheries Laboratory for sending fish sera and for enabling me to visit the Arctic in the summer of 1956 to collect the cod and haddock sera.

Department of Zoology,

University College,

Cork. Jan. 12 .

${ }^{1}$ Boyden, A., and Defalco, R. J., Physiol. Zool., 16, 229 (1943).

\section{Cephalotoxin : the Crab-paralysing Agent of the Posterior Salivary Glands of Cephalopods}

THE presence of a substance, toxic to crabs, in the posterior salivary glands of cephalopods (Giftdrusen of the German authors) has been known for a long time $^{\mathrm{I}}$. When a drop of saliva collected from Octopus is injected into a crab, a sequence of reactions is observed followed by complete paralysis of the animal ${ }^{2}$. Active substances have been extracted from the posterior salivary glands of octopuses ${ }^{3}$, and their presence has been demonstrated in external and internal secretions ${ }^{4}$. Most of these substances have a powerful action on crabs and upon isolated organs of molluses and other invertebrates ${ }^{5}$. Tyramine, the substance first isolated from the glands by Henze ${ }^{6}$, was, and still is, believed to be the toxie agent? However, none of the extractive substances found in the posterior salivary glands of cephalopods, even tyramine, can reproduce the paralysing action of the crude extracts or of saliva. The observations of Livon and Briot ${ }^{8}$, recently confirmed by $\mathrm{me}^{9}$, claim a more complex composition. The active principle is inactivated by heating, does not pass through dialysing membranes and can be purified by precipitation with ammonium sulphate.

From the posterior salivary glands of Sepia officinalis we have now purified a protein which, when injected into crabs, has the same effect as the dialysed extract from the same organ. The active protein has been called cephalotoxin.

As a measure of purification an arbitrary unit was taken which is defined as the amount of toxin which paralyses in $15 \mathrm{~min}$. a crab weighing $40-50 \mathrm{gm}$. The animal used in all the experiments was the crustacean decapod Eriphia spinifrons. Control animals were injected with equal amounts of extract previously heated at $100^{\circ} \mathrm{C}$. for $5 \mathrm{~min}$. Specific activity was calculated as units per mgm. of protein. The protein content was determined colorimetrically with the Folin-phenol reagent ${ }^{10}$. 